\title{
AN EXPERIMENT TO DEVELOP CONVERSION FACTORS TO STANDARDISE MEASUREMENTS OF AIRBORNE ASBESTOS
}

\author{
Metoda DODIČ-FIKFAK \\ Clinical Institute of Occupational Medicine, University Medical Centre, Ljubljana, Slovenia
}

Received in June 2006

Accepted in March 2007

\begin{abstract}
Various researchers and agencies recommend different conversion factors for different asbestos exposures. The aim of this study was to develop conversion factors from particles per $\mathrm{cm}^{3}\left(\mathrm{p} \mathrm{cm}^{-3}\right)$ to fibres per $\mathrm{cm}^{3}$

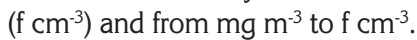

More than 1000 exposure measurements were available in the Slovenian asbestos-cement factory Salonit Anhovo. Three types of measurement of asbestos concentrations in the air were used: a konimeter measuring $\mathrm{p} \mathrm{cm}^{-3}$, a gravimetric method measuring $\mathrm{mg} \mathrm{m}^{-3}$ and a membrane filter method measuring $\mathrm{f} \mathrm{cm}^{-3}$. Operation-specific conversion factors among these methods were developed. One conversion factor was obtained for asbestos-pipe-dry jobs (4.7) and one for asbestos-sheet-dry jobs (1.6). Only one conversion factor (0.8) was used for asbestos-cement-pipe-wet and asbestos-cement-pipe-dry jobs. For asbestos cement sheets, two conversion factors were obtained (0.3 and 1.2).

The development of five different conversion factors made it possible to calculate cumulative exposure to asbestos from historical data and to decrease exposure misclassification.
\end{abstract}

KEY WORDS: asbestos exposure, cement-asbestos industry, gravimetric method, konimeter, membrane filter method

The need to express exposure in only one unit of measurement arose when it became desirable to evaluate the association of cumulative exposure for particular workers or for groups of workers with the risk of developing a disease.

Researchers and agencies recommended different conversion factors. The most widely accepted conversion factor in Europe is that of the European Community Directive concerning the prevention of asbestos pollution in the environment $(1,2)$. This directive specifies that a conversion factor of 2 fibres per millilitre $\left(\mathrm{f} \mathrm{mL}^{-1}\right)=0.1 \mathrm{mg} \mathrm{m}^{-3}$ asbestos dust "may be used" to make gravimetric measurements comparable to fibre number concentrations in $\mathrm{fmL}^{-1}$. German BK-Report 1/97 "Faserjahre" proposed a conversion factor of $5 \mathrm{f} \mathrm{mL}^{-1}=0.1 \mathrm{mg} \mathrm{m}^{-3}$ for asbestos dust (3). The report continued that, because of inconsistent results in literature, this factor was only to be used when necessary. Dement et al. developed a conversion factor between the impinger and membrane filter data (4). In a linear correlation they also took plant operations into account. A conversion factor of $7.8 \mathrm{f} \mathrm{cm}^{-3}$ per million particles per cubic foot (mpcf) for fibres $>5 \mu \mathrm{m}$ in length was calculated for jobs involving the highest asbestos exposure (preparation). For the rest of the jobs, a mean conversion factor of $2.9 \mathrm{f} \mathrm{cm}^{-3}$ per mpcf was used (4). In the study of dose-response relationship for asbestos exposure in a chrysotile textile factory, Huang (1990) developed new conversion factors. He sampled airborne dust concentration using both the gravimetric and fibre counts at the same time for various workplaces. Conversion factors from geometric dust concentration into fibre concentrations for each workplace was estimated by a regression analysis. It is not clear from the article which variables the author included in the regression model (5). Count-to-mass conversion factors for asbestos present in stack emission were calculated by Puledda and Marconi (6). The conversion factor was defined as the ratio between fibre surface density and mass surface density. The values in asbestos cement sheet production ranged 
from $0.07 \mathrm{f} \mathrm{cm}^{-3}=0.1 \mathrm{mg} \mathrm{m}^{-3}$ to $0.4 \mathrm{f} \mathrm{cm}^{-3}=$ $0.1 \mathrm{mg} \mathrm{m}^{-3}$ and in asbestos cement pipe production from $0.05 \mathrm{f} \mathrm{cm}^{-3}=0.1 \mathrm{mg} \mathrm{m}^{-3}$ to $0.35 \mathrm{f} \mathrm{cm}^{-3}=$ $0.1 \mathrm{mg} \mathrm{m}^{-3}$. Harries compared mass and fibre number concentrations of asbestos dust in shipyard insulation processes (7). He concluded that three dust indices

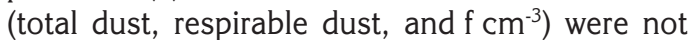
sufficiently precise for any one of them to be accurately derived from the other. Kopczyk-Myszlon carried out an investigation of railway jobs, comparing two indices of air contamination using a regression analysis: gravimetric determination of asbestos-containing dust

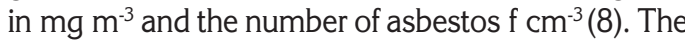
resultant conversion factors ranged from $0.03 \mathrm{f} \mathrm{cm}^{-3}$ $=0.1 \mathrm{mg} \mathrm{m}^{-3}$ to $0.06 \mathrm{f} \mathrm{cm}^{-3}=0.1 \mathrm{mg} \mathrm{m}^{-3}$. In their article about interconvertibility of asbestos fibre count concentration, Valić and Cigula stated that no single conversion factor could be used to reliably convert the konimeter and thermal precipitator measurements to membrane filter asbestos fibre concentrations (9). In a meta-analysis of the relation between cumulative exposure to asbestos and relative risk of lung cancer, Lash et al. used different conversion factors for each of the three industries for studies reporting cumulative exposure categories in units other than $\mathrm{f} \mathrm{cm}^{-3}$-years (10). They used a conversion factor of $1.4 \mathrm{x}$ mpcf-years per $\mathrm{f} \mathrm{mL}^{-1}$-years for cement and manufacturing industries. Gibbs reviewed the reliability of converting results by the midget impinger, a long running and regular thermal precipitator to membrane filter equivalent concentrations. He also stressed that conversion involved considerable uncertainty (11). In measurement reports in the investigated plant Salonit Anhovo, local investigators used the EC conversion factor of $0.1 \mathrm{mg} \mathrm{m}^{-3}=2 \mathrm{f} \mathrm{cm}^{-3}$ or the proposed German conversion factors of $0.1 \mathrm{mg} \mathrm{m}^{-3}$ $=5 \mathrm{f} \mathrm{cm}^{-3}$ for departments where only asbestos was used and $0.1 \mathrm{mg} \mathrm{m}^{-3}=1 \mathrm{f} \mathrm{cm}^{-3}$ in asbestos-cement departments (12) (Table 1).

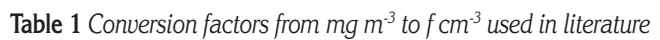

\begin{tabular}{|c|c|}
\hline Study or Institution & 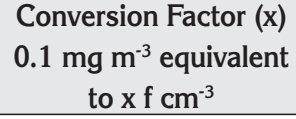 \\
\hline $\begin{array}{l}\text { European Community Directive } \\
\text { 87/217/EEC }\end{array}$ & 2 \\
\hline BK -Report 1/97 "Faserjahre" & 5 \\
\hline Pulleda, Marconi, 1991 & $0.05-0.4$ \\
\hline Kopczyk-Myszlon, 1984 & $0.03-0.06$ \\
\hline $\begin{array}{l}\text { Institute of Occupational Safety, } \\
\text { Maribor, SI, } 1986\end{array}$ & $\begin{array}{c}5 \text { (for asbestos dust) } \\
1 \text { (for asbestos-cement } \\
\text { dust) }\end{array}$ \\
\hline
\end{tabular}

The aim of our study was to develop conversion

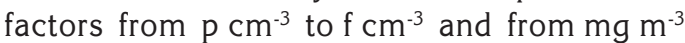

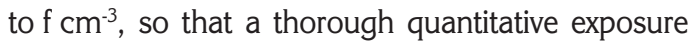
reconstruction from the extensive available historical data (measured in three different units) could be completed for an epidemiological study of the doseresponse effect of cumulative exposure to asbestos and lung cancer.

\section{METHODS}

The study took place in Salonit Anhovo, the only cement-asbestos plant in Slovenia. There were three activities or major production areas of the plant: cement production (cement production and clinker production in two cement factories), production of asbestos-cement pipes and corrugated sheets, and production of polyethylene and Man - Made Mineral Fibres (MMMF) pipes, which began in 1990. Cement asbestos production began in 1922.

There were two departments in the asbestoscement production plant: Asbestos-cement pipe manufacture department and Asbestos-cement sheet manufacture department (Table 2).

Table 2 Principal operations in two departments: Asbestos-cement pipe manufacture department and Asbestos-cement sheet manufacture department

\begin{tabular}{ll}
\hline $\begin{array}{l}\text { Asbestos-cement } \\
\text { pipe manufacture } \\
\text { department }\end{array}$ & $\begin{array}{l}\text { Asbestos-cement sheet } \\
\text { manufacture department }\end{array}$ \\
\hline $\begin{array}{l}\text { A. Preparation of } \\
\text { asbestos mixture }\end{array}$ & $\begin{array}{l}\text { A. Preparation of asbestos } \\
\text { mixture }\end{array}$ \\
$\begin{array}{ll}\text { B. Preparation of } \\
\text { asbestos-cement }\end{array}$ & $\begin{array}{l}\text { B. Preparation of } \\
\text { asbestos-cement } \\
\text { suspension }\end{array}$ \\
$\begin{array}{l}\text { C. Pipe forming and } \\
\text { curing }\end{array}$ & $\begin{array}{l}\text { C. Sheet forming, curing } \\
\text { and finishing }\end{array}$ \\
$\begin{array}{ll}\text { D. Pipe finishing } & \text { D. Hand-moulding of } \\
\text { small products }\end{array}$ \\
$\begin{array}{l}\text { E. Transport of asbestos E. Transport of asbestos } \\
\text { and products }\end{array}$ & and products \\
\hline
\end{tabular}

The principal operations in the asbestos-cement factory were: material preparation, mixing and forming, curing and finishing. At the Anhovo facility, part of the wet-pressed asbestos cement material was used to hand-mould small sheet products. Different moulds, lathes, saws and mills were used to form the pipe. Exposure circumstances had not changed 
substantially by 1985 , when workers began to use respirators, although they did not use them regularly. Dry operations started in 1964 and were completed in 1968.

All air sampling measurements were taken at fixed locations where samples were collected close to a workers' breathing zone. The air sampling stations remained the same throughout the monitoring program. Air sampling stations in the plant were located at workplaces not polluted by dust; workplaces polluted by dust, but having ventilation systems installed; and polluted workplaces with no ventilation installed. The most polluted workplaces were: preparation of asbestos and asbestos cement mixtures, emptying and cleaning asbestos mixing chambers, grinding asbestos products, producing insulation material, and boring holes in corrugated cement asbestos sheets.

The monitoring of airborne fibre concentrations in the facility (mostly for compliance) began in 1961 and continued until the end of 1996. Several different monitoring methods were used and altogether about 1030 air measurements from the asbestos factory are now available for the period from 1961 to 1995 (Tables 3, 4 and 5).

Table 3 Monitoring methods used in different time periods

\begin{tabular}{lll}
\hline Period & Method & $\begin{array}{l}\text { Unit of } \\
\text { measurement }\end{array}$ \\
\hline 1961-1972 & Konimeter & $\mathrm{p} \mathrm{cm}^{-3}$ \\
1974-1975 & Membrane filter & $\mathrm{f} \mathrm{cm}^{-3}$ \\
1976-1985 & Gravimetry & $\mathrm{mg} \mathrm{m}^{-3}$ \\
1985-present & Membrane filter & $\mathrm{f} \mathrm{cm}^{-3}$ \\
\hline
\end{tabular}

The local Public Health Institute made the first measurements at this facility using Carl-Zeiss konimeters with $5 \mathrm{~cm}^{3}$ air samples in 1961; these konimeters were used in Slovenia in the 1960s and 1970s (Zeiss Konimeter). They consisted essentially of a small valve-less spring-operated piston pump and a circular plate for impingement of dust. The piston could be used to create, at the discretion of the operator, a $2.5 \mathrm{~mL}$ or $5 \mathrm{~mL}$ void, pulling atmospheric air through a round $0.5 \mathrm{~mm}$ to $0.6 \mathrm{~mm}$ orifice and impinging it against a circular glass plate held $0.5 \mathrm{~mm}$ to $0.6 \mathrm{~mm}$ distant from and perpendicular to the impinging orifice. A circular plate was covered with an adhesive film to retain the dust particles and had 30 numbered, equally spaced sample positions. Usually several samples were taken with a konimeter in the same work area in order to estimate average conditions. The konimeter asbestos measurements were expressed as $\mathrm{p} \mathrm{cm} \mathrm{cm}^{-3}(13)$.

The gravimetric method was used from 1975 to 1981. From 1981 to 1986 both the gravimetric and the membrane filter methods were used. The gravimetric method is the simplest analytical technique for dust measurement and can be used for the determination of particulate matter sampled on filter paper, in an impinger, or in an electrostatic precipitator. In the 1980s, Slovenian institutions used the VC-25, a device agreed to be used in several EU countries for the measurement of alveolar and total dust from consistent dust sources. The quantity of asbestos was analyzed only in the respirable fraction (defined as $<8 \mu \mathrm{m}$ of aerodynamic diameter) of the air sample. Dust concentration was measured radiometrically by beta particle absorption. The results were expressed as milligrams of respirable dust per cubic meter of air $\left(\mathrm{mg} \mathrm{m}^{-3}\right)$.

From 1987 to 1996 , only the membrane filter method was used. This is the reference method for the determination of airborne asbestos fibre concentrations by light microscopy. The first results from Salonit using this method are from 1974/75. A sample was collected by drawing a measured quantity of air through a membrane filter $(25 \mathrm{~mm}$ diameter, $1.2 \mu \mathrm{m}$ pore size, with printed counting grids) using a battery-powered sampling pump. The fibres were sized and counted using a phase contrast microscope. Graticule areas for counting were chosen at random within the exposed area on the filter and up to 100 graticule areas were counted. Countable fibres were defined as any object having a maximum diameter less than $3 \mu \mathrm{m}$, maximum length greater than $5 \mu \mathrm{m}$, and length-to-diameter ratio greater than 3:1. The final result is expressed as fibres per millilitre of air (f $\left.\mathrm{mL}^{-1}\right)(14,15)$.

Table 4 Number of air measurements in asbestos factory for the period from 1961 to 1995

\begin{tabular}{lcccc}
\hline Period & $1961-1972$ & $1974-1975$ & $1976-1985$ & $1985-1994$ \\
\hline Number & 293 & 16 & 169 & 561 \\
\hline
\end{tabular}


Table 5 Paired airborne dust and fibre concentration measurements by job in the sheet department with corresponding information regarding process type

\begin{tabular}{|c|c|c|c|c|c|}
\hline Job Title & $\frac{\text { Ratio }}{\mathrm{f} \mathrm{cm}^{-3} / \mathrm{mg} \mathrm{m}^{-3}}$ & $\frac{\text { Dust }}{\mathrm{mg} \mathrm{m}^{-3}}$ & $\begin{array}{c}\text { Fibre } \\
\text { concentration } \\
\frac{\mathrm{f} \mathrm{cm}^{-3}}{}\end{array}$ & $\begin{array}{c}\text { Process } \\
\text { type }\end{array}$ & Product type \\
\hline $\begin{array}{l}\text { Preparation of } \\
\text { asbestos mixture }\end{array}$ & $\begin{array}{c}0.81 \\
11.36\end{array}$ & $\begin{array}{c}12.4 \\
1.1\end{array}$ & $\begin{array}{l}10.0 \\
12.5\end{array}$ & dry & asbestos \\
\hline Disintegrator & 0.80 & 0.5 & 0.4 & dry & asbestos \\
\hline $\begin{array}{l}\text { Preparation of } \\
\text { asbestos }\end{array}$ & 0.91 & 1.1 & 1.0 & dry & asbestos \\
\hline Decanter & 1.29 & 0.7 & 0.9 & dry & asbestos-cement \\
\hline $\begin{array}{l}\text { Preparation of asb- } \\
\text { cement suspension }\end{array}$ & 0.10 & 21.2 & 2.2 & dry & asbestos-cement \\
\hline $\begin{array}{l}\text { Between machine } \\
2,3,4\end{array}$ & 0.29 & 1.4 & 0.4 & wet & asbestos-cement \\
\hline $\begin{array}{l}\text { Between machine } \\
\text { 3\&4 }\end{array}$ & 0.40 & 0.5 & 0.2 & wet & asbestos-cement \\
\hline Display-5 machine & 0.13 & 6.3 & 0.8 & wet & asbestos-cement \\
\hline $\begin{array}{l}\text { Cleaning asb-cem } \\
\text { molds }\end{array}$ & $\begin{array}{l}0.04 \\
0.93\end{array}$ & $\begin{array}{l}5.4 \\
5.5\end{array}$ & $\begin{array}{l}0.2 \\
5.1\end{array}$ & wet & asbestos-cement \\
\hline Fasoni painting & $\begin{array}{l}0.12 \\
1.11\end{array}$ & $\begin{array}{c}35.0 \\
4.6\end{array}$ & $\begin{array}{l}4.1 \\
5.1\end{array}$ & dry & asbestos-cement \\
\hline $\begin{array}{l}\text { Cutting asb-cem } \\
\text { material }\end{array}$ & 1.36 & 0.1 & 0.2 & wet & asbestos-cement \\
\hline $\begin{array}{l}\text { Grinding asb-cem } \\
\text { material }\end{array}$ & $\begin{array}{c}25.00 \\
8.30\end{array}$ & $\begin{array}{l}0.3 \\
1.5\end{array}$ & $\begin{array}{c}8.0 \\
12.4\end{array}$ & dry & asbestos-cement \\
\hline 34 RBP & 0.80 & 46.0 & 39.0 & dry & asbestos-cement \\
\hline Shoe sawing & 1.43 & 0.1 & 0.2 & dry & asbestos-cement \\
\hline
\end{tabular}

Conversion factors were developed to combine data gathered by different exposure assessment methods:

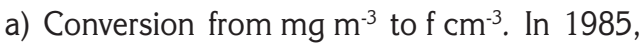
1986, 1987 and 1989, industrial hygienists collected side by side air samples using the gravimetric and membrane filter methods. This produced a total of 78 paired measurements, 60 measurement pairs in the pipe and 18 measurement pairs in the sheet manufacture department. Because of the limited number of data points, a non-parametric method was chosen to calculate conversion factors between $\mathrm{mg} \mathrm{m}^{-3}$ and $\mathrm{f} \mathrm{cm}^{-3}$. Judging by earlier studies, it is likely that the product and process factors determine airborne fibre. All paired data were divided according to product (asbestos or asbestos-cement), department (sheet, pipe) and process (wet or dry). For each pair we calculated the ratio between $\mathrm{f} \mathrm{cm}^{-3}$ and $\mathrm{mg} \mathrm{m}^{-3}$ and grouped these ratios into two groups: asbestos and asbestos-cement. The geometric means of the ratios were calculated for each group. Ratios were grouped further into asbestos-pipe and asbestos-sheet groups, and asbestos-cement-pipe and asbestoscement-sheet groups, and the geometric means for each of the groups were calculated. Finally, the type of the process - wet or dry - was taken into account, totalling to 8 groups, each for different product and process combinations: asbestos-pipe-dry, asbestospipe-wet, asbestos-sheet-dry, asbestos-sheet-wet, asbestos-cement-pipe-dry, asbestos-cement-pipe-wet, asbestos-cement-sheet-dry, asbestos-cement-sheetwet. Each group was calculated the geometric mean of ratios. Table 5 and Figure 1 show a calculation of conversion factors in the sheet department.

b) Conversion from $\mathrm{p} \mathrm{cm}^{-3}$ to $\mathrm{f} \mathrm{cm}^{-3}$. No sideby-side sample measurements of $\mathrm{f} \mathrm{cm}^{-3}$ and $p \mathrm{~cm}^{-3}$ were available from the period when the konimeter was used. In 1974/75, 16 measurements were made using the membrane filter method, yielding measurements of $\mathrm{f} \mathrm{cm}^{-3}$. The nearest measurements $(\mathrm{n}=31)$ in $\mathrm{p} \mathrm{cm}^{-3}$ were those available from 1969. These 16 and 31 measurements were grouped by product, department and process in the same way as shown in Figure 1. When more than one sample 
was available for a particular product, department or process combination, the geometric mean was calculated.

The conversion factors were needed in the nested case-control study conducted in a cohort of almost 7000 workers employed for at least one day in the Slovenian asbestos-cement factory, where the authors calculated a separate cumulative lifetime exposure to asbestos (16).

\section{RESULTS}

All workplaces with exposure only to asbestos in the pipe and sheet departments were dry, so only one conversion factor was obtained for asbestos-pipe-dry jobs and one for asbestos-sheet-dry jobs. Asbestoscement-pipe-wet jobs were heavily influenced by dry process emissions, because the pipe finishing process was located nearby. The conversion ratios were also close: 0.9 and 0.7 . Therefore, it was decided to use one conversion factor (0.8) for asbestos-cement-pipewet and asbestos-cement-pipe-dry jobs. For asbestos cement sheets, two conversion factors were obtained (0.3 and 1.2). Altogether, five different conversion factors to convert measurements from $\mathrm{mg} \mathrm{m}^{-3}$ to $\mathrm{f} \mathrm{cm}^{-}$ ${ }^{3}$ were obtained for the two departments (Figure 1).

\section{DISCUSSION AND CONCLUSION}

The need for conversion factors to express exposure to asbestos in only one unit of measurement appeared when researchers began to evaluate the association of cumulative exposure for group of workers with a risk of disease. The development of accurate conversion factors between different methods used to collect and analyze asbestos dust has been a major problem in the assessment of asbestos exposure for all epidemiological studies.

Almost all calculated conversion factors are an approximation. The group of authors in Germany who proposed 2.5 times greater conversion factor than those proposed by the EC suggested that, because of the inconsistent results in literature, this factor should be used only if necessary (3). Other authors also warned about the great variability of calculated conversion factors. Harries (1971) concluded that the three dust indices, total dust, respirable dust, and fibres per $\mathrm{cm}^{3}$, were not sufficiently precise for any one of them to be accurately derived from another. $\mathrm{He}$ found a very poor correlation between the total dust mass concentration and fibre number concentration (17). Valić and Cigula stated that no single conversion factor could be used to reliably convert koniometer and thermal precipitator measurements to membrane filter asbestos fibre concentration. They proposed that a separate conversion factor needed to be derived for each technological process (9). A Slovenian researcher expressed doubts about possible correlations between the values obtained by two different methods (gravimetric and using konimeter) regardless of the fibre type. He compared 47 paired results in the textile (non-asbestos) industry obtained by the gravimetric method and by konimeter. Calculated correlation coefficients ranged from 0.3 to 0.6 (18). Gibbs reviewed the reliability of conversion factors and concluded that no overall single factor could be derived for mining and milling, but it was possible to derive conversion factors at the individual mill and work area level. Even so, he stated that conversions involved considerable uncertainty (11). Only Dement et al. (1987) have given a detailed explanation of the conversion factors used (4). Unfortunately, Dement's

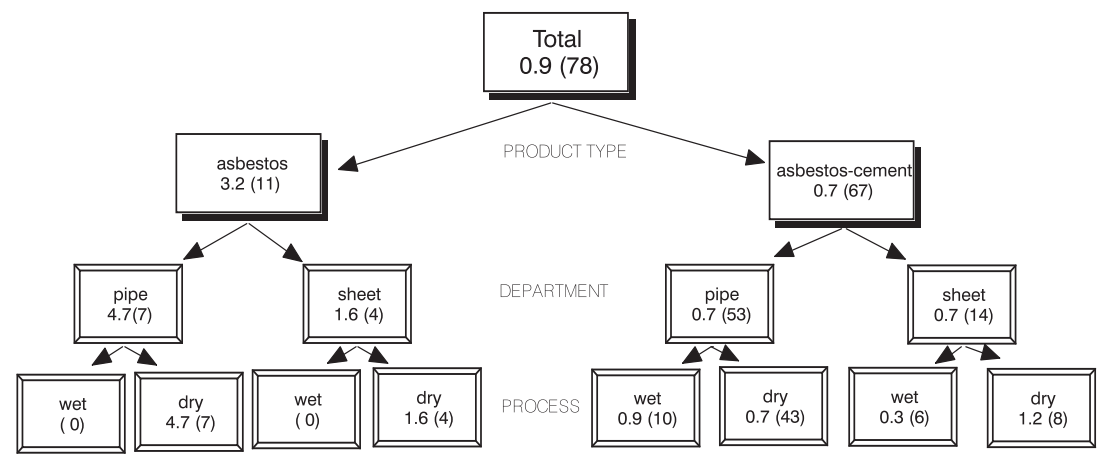

Figure 1 Classification tree: Conversion factors $\left(f \mathrm{~cm}^{-3} / \mathrm{mg} \mathrm{m}^{-3}\right)$ and the number of observed ratios in each group (in parenthesis) (14) 
conversion factors are not likely to be applicable to those developed here because they were developed for the asbestos textile manufacturing. Other studies do not give sufficient information to evaluate their conversion factors.

To calculate the conversion factor for our study, a nonparametric method was used because of a limited number of available paired data. As recommended earlier (19), the conversion factors developed in this study take into account product and process characteristics related to the number of fibres in the total airborne dust generated during various asbestos manufacturing operations. This is an advantage of this study, although the degree to which various product and process characteristics affect the airborne fibre concentration is not known.

The developed conversion factors were generally lower than the EC factor of $2 \mathrm{f} \mathrm{cm}^{-3}$ per $0.1 \mu \mathrm{g} \mathrm{m}^{-3}$. The EC also does not give a full explanation of the development of their conversion factor and they acknowledge similar difficulties with recommending such factors. Although I am fully aware of the limitations of the study related to the nonparametric method used and to the doubt whether conversion from one method of unit of measurement to another is possible, I believe that there is hardly a more appropriate method to use from available data.

\section{REFERENCES}

1. Council of the European Communities. Council Directive of 19 September 1983 on the protection of workers from the risks related to exposure to asbestos at work. Second individual directive within the meaning of article 8 of Directive 80/1107/EEC. Off $\mathrm{J}$ Eur Commun 1983;25-32.

2. Council of the European Communities. Council Directive of 19 March 1987 on the prevention and reduction of environmental pollution by asbestos. Off J Eur Commun 1987;40-5.

3. Bauer HD, Blome H, Gelsdorf H. Umrechnungsfaktoren der Meßverfahren (Conversion factors of measuring methods). BK Report Faserjahre 1997;1:64-5.

4. Dement JM, Harris RL, Symons MJ, Shy cm. Exposures and mortality among chrysotile asbestos workers. Part I: Exposure estimates. Am J Ind Med 1983;4:399419.

5. Huang JQ. A study on the dose-response relationship between asbestos exposure level and asbestosis among workers in a Chinese chrysotile product factory. Biomed Environ Sci 1990;3:90-8.
6. Pulleda S, Marconi A. Study of the Count-to-mass conversion factor for asbestos fibres in samples collected at the emissions of three industrial plants. Ann Occup Hyg 1991;35:517-24.

7. Harries PG. A comparison of mass and fibre concentrations of asbestos dust in shipyard insulation processes. Ann Occup Hyg 1971;14:235-40.

8. Kopczyk-Myszlon T. Vergleichsanalyse der Indexe fuer Asbeststaubverunreinigung (Comparative analysis of indices for contamination with asbestos dust). Arbeitsmed Sozialmed Praeventivmed 1984;19:6-8.

9. Valić F, Cigula M. Interconvertibility of asbestos fibre count concentrations recorded by three most frequent methods. Arh Hig Rada Toksikol 1992;43:359-64.

10. Lash TL, Crouch EA, Green LC. A meta-analysis of the relation between cumulative exposure to asbestos and relative risk of lung cancer. Occup Environ Med 1997;54:254-63.

11. Gibbs GW. The assessment of the exposure in terms of fibres. Ann Occup Hyg 1994;38:477-87.

12. Institute of Occupational Safety. Maribor Centre for the Protection of Environment. The measurements of dust concentration and the concentration of asbestos fibres in Salonit Anhovo, Sheets subsidiary. Maribor: Institute of Occupational Safety; 1986.

13. Brozek J, Curtiss LF, Dart EE. The Konimeter. In: Patty FA, editor. Industrial Hygiene and Toxicology. Vol 1. New York (NY): Interscience Publishers; 1948. p. 217.

14. Asbestos International Association (AIA). Health and safety publication. Recommended technical method No. 1 (RTM1). Reference method for the determination of airborne asbestos fibre concentrations at workplaces by light microscopy (Membrane filter method). London: AIA; 1987. p. 1-8.

15. Mirtič $B$. The determination of the content of asbestos fibres in the respirable dust. Mining and Metallurgy Quarterly 1989;36:281-8.

16. Dodič Fikfak M. Lung cancer and exposure to amphiboles and chrysotile [dissertation]. University of Massachusetts Lowell; 1998.

17. Harries PG. A comparison of mass and fibre concentrations of asbestos dust in shipyard insulation processes. Ann Occup Hyg 1971;14:235-40.

18. Gspan P. A comparison of a gravimetric method and a method with counting dust particles to assess the amount of dust in a working environment.. Delo in varnost 1985; 30:11-12.

19. Quinn mm, Smith TJ, Ellenbecker MJ, Wegman DH, Eisen EA. Biologically Based Indices of Exposure to Fibres for Use in Epidemiology. Occupational Hygiene 1996;3:103-11. 


\title{
Sažetak
}

\section{RAZVOJ KONVERZIJSKIH FAKTORA ZA STANDARDIZACIJU MJERENJA IZLOŽENOSTI AZBESTU U ZRAKU}

Različiti istraživači i agencije preporučili su upotrebu različitih konverzijskih faktora za ekspoziciju azbestu kako bi se mogla izraziti ekspozicija u samo jednoj mjernoj jedinici. Cilj ove studije bio je izračunati faktore konverzije iz čestica $\mathrm{cm}^{-3} \mathrm{u}$ vlakna $\mathrm{cm}^{-3} \mathrm{i}$ iz $\mathrm{mg} \mathrm{cm}^{-3} \mathrm{u}$ vlakna $\mathrm{cm}^{-3}$, tako da bismo mogli iz dostupnih historijskih podataka izračunati kvantitativnu ekspoziciju za epidemiološku studiju o efektu odgovor-doza za kumulativnu ekspoziciju azbestu i rak pluća.

Za sva radna mjesta u slovenskoj tvornici cement-azbesta Salonit Anhovo imali smo više od 1000 izmjerenih uzoraka zraka. Za mjerenje koncentracije azbesta u zraku upotrijebili smo tri različite tehnike: konimetar, koji mjeri broj čestica na kubni centimetar, gravimetrijsku metodu, koja mjeri miligrame na kubni metar i metodu membranskog filtra, koji mjeri vlakna na kubni centimetar. Faktore konverzije između rezultata navedenih metoda izračunali smo s pomoću seta 78 parnih uzoraka, koji su istodobno analizirani membranskofiltarskom i gravimetrijskom metodom i manjeg seta uzoraka analiziranih konimetrom i membranskofiltarskom membranom. Ove faktore konverzije naknadno smo upotrijebili u ispitivanju kohorte koja je imala gotovo 7000 radnika za izračun kumulativne ekspozicije za svaki primjer i svaku kontrolu. Jedan konverzijski faktor $(4,7)$ dobiven je za suha radna mjesta u azbest-cementnoj proizvodnji cijevi i jedan za suha radna mjesta u azbest-cementnoj proizvodnji krovnih ploča $(1,6)$. Mokra azbest-cementna radna mjesta u proizvodnji cijevi bila su pod velikim utjecajem okolnih suhih emisija, zato smo odlučili upotrijebiti samo jedan konverzijski faktor $(0,8)$ za suhu i mokru proizvodnju azbest-cementne industrije cijevi. Za proizvodnju krovnih ploča izračunana su dva konverzijska faktora $(0,3$ i 1,2$)$.

Razvoj pet različitih faktora konverzije, karakterističnih za azbest-cementnu industriju, omogućilo je izračun kumulativne ekspozicije azbestu iz ekstenzivne historijske dokumentacije, a smanjila se i pogrešna klasifikacija ekspozicije koja bi bila prisutna ako bi autori rabili samo jedan faktor konverzije.

KLJUČNE RIJEČI: azbest-cementna industrija, gravimetrijska metoda, konimetar, kumulatiuna izloženost, metoda membranskog filtra

\section{CORRESPONDING AUTHOR:}

\author{
Metoda Dodič Fikfak, MD, PhD \\ Inštitut za medicino dela, prometa in športa \\ Klinični center \\ Poljanski nasip 58, SI-1000 Ljubljana \\ E-mail: metoda.dodic-fikfak@guest.arnes.si
}

